\title{
A AUTORIDADE NORMATIVA DAS PRÁTICAS COMPARTILHADAS: UMA INTERPRETAÇÃO DA INTRODUÇÃO À FILOSOFIA DO DIREITODE HEGEL
}

\author{
Erick Lima
}

Universidade de Brasília

\begin{abstract}
Resumo: Algumas discussões contemporâneas têm sido bastante influenciadas pela teoria hegeliana da normatividade. Gostaria de propor aqui uma leitura da Introdução à Filosofia do Direito fortemente inspirada na ideia de uma ontologia social constituída pela autoridade normativa das práticas compartilhadas, salientando as diretrizes hegelianas em debates contemporâneos na filosofia prática e na teoria social. Primeiramente, procuro acessar a teoria hegeliana da liberdade como respostas ao desafio moderno de se pensar a autodeterminação de maneira unilateral (1). Em seguida, procuro compreender a noção hegeliana de direito à luz das questões postas pela modernidade política (2). Concluo indicando o impacto da noção hegeliana de direito no escopo geral da filosofia prática (3).
\end{abstract}

Palavras-chave: direito, G.W.F. Hegel, normatividade, prática, liberdade

\begin{abstract}
Some contemporary discussions in philosophy have been considerably influenced by Hegel's account of normativity. I would like to propose here an interpretation of Hegel's Introduction to the Philosophy of Right inspired by the idea of a social ontology, constituted by the normative authority of social practices, in order to point out Hegel's contribution to contemporary issues in practical philosophy and social theory. To begin with, the paper aims at presenting how Hegel's theory of practical freendom intends to respond to the challenge of thinking self-determination less unilaterally (1). Then I attempt to comprehend Hegel's notion of right in the context of the issues created by political modernity (3). I conclude by showing the influence of Hegel's notion of right in the conceptual framework of practical philosophy.
\end{abstract}

Keywords: right, G.W.F. Hegel, normativity, practice, freedom 
O que reside entre a razão como espírito consciente de si e a razão enquanto efetividade existente, o que separa aquela razão desta, não permitindo que encontre nela a satisfação, são os grilhões de um qualquer abstraktum, que não se libertou para o conceito. Reconhecer a razão como a rosa na cruz do presente e, a partir disso, regozijar-se / com ela: esta visualização racional (vernünftige Einsicht) é a conciliação (Versöhnung) com a efetividade que a filosofia concede àqueles aos quais uma vez sobreveio a exigência interior de compreender e conservar igualmente, naquilo que é substancial, a liberdade subjetiva, assim como também não se deter, com a liberdade subjetiva, em algo particular e contingente, mas, antes, naquilo que é em si e para si. (HEGEL, 1970, 7, p. 25/26).

Considero que a compreensão proposta por Honneth para o conceito hegeliano de eticidade (Sittlichkeit) toma uma direção que retém o que parece ser ainda um potencial inesgotável na filosofia prática de Hegel, aquilo que, por sinal, estabelece as condições para uma conexão entre a filosofia prática e a teoria social pela via de uma percepção pragmatista da "ontologia social". É interessante perceber como Honneth se deixa afetar por um "pragmatismo ético" de inspiração hegeliana no contexto da

\footnotetext{
1 Uma consideração da diferença entre moralidade e eticidade em termos da relação entre "intersubjetividade" e "objetividade" (PIPPIN, 2008, 262) facilita a percepção das linhas gerais de um pragmatismo ético. A "normatividade inerente às nossas práticas de conhecimento e ação é irredutível, e a relação entre natureza e espírito, de causalidade e normatividade, deixa-se descrever de forma apropriada somente desde o interior dessas práticas" (QUANTE, 2004, 13). Quante sustenta a ideia de que Hegel apresenta vários paralelos com o modelo de pragmatismo defendido por Putnam, sobretudo no que diz respeito ao "primado do prático sobre o teórico", à "recusa da dicotomia entre normas e valores", ao "falibilismo" na filosofia prática (QUANTE, 2011, p. 287) e a uma "posição fundamentalmente anticética" (Idem, p. 280). "A crítica de Hegel ao formalismo e ao ceticismo ético, sua defesa de um realismo ético com respeito a práticas sociais e sua adesão a uma concepção de ética materialmente enriquecida, são características teóricas que se contrapõem a alguns desenvolvimentos na ética e na metaética contemporânea. Como para Hegel as práticas sociais são para elas fundacionais, deixam-se nele encontrar traços fundamentais de um pragmatismo ético" (QUANTE, 2004, p. 10-11). Quante conclui que "a tese hegeliana acerca da superação da moralidade na eticidade é para ser interpretada não de um ponto de vista da teoria da validade... mas da perspectiva de uma teoria da fundamentação. Com outras palavras, trata-se para Hegel não de provar que as pretensões de validade da eticidade devem predominar sobre as pretensões de validade da moralidade, mas antes de mostrar, em primeiro lugar, que toda argumentação moral tem de se apoiar sobre premissas éticas pressupostas" (QUANTE, 2011, p. 287). Nesse sentido, o argumento hegeliano de "superação da moralidade na eticidade" se deixa ler como uma "estratégia pragmatista de fundamentação" (Idem, p. 293): "que uma eticidade vivida na práxis e que se conserva nela não necessita de nenhuma justificação por um princípio da razão prática, a qual se apoiaria em pressuposições exteriores. Tal fundamentação filosófica, caso ela se
} 
passagem de sua versão da teoria crítica para a teoria da justiça. De fato, parece-me, é uma inspiração desse tipo que está em jogo na pretensão de desenvolver a tese hegeliana acerca de um "entrelaçamento entre racionalidade e realidade social" (ADORNO; HORKHEIMER, 1988, p. 15). Acerca da proveniência hegeliana dessa orientação na teoria crítica, Honneth menciona que "[os teóricos críticos] sustentam uma conexão interna entre as relações patológicas e a condição da racionalidade social... A tese de que as patologias sociais devem ser entendidas como resultado da racionalidade deficiente é tributária basicamente da filosofia política de Hegel" (HONNETH, 2008, p. 393).

Boa parte da inspiração hegeliana presente nesse horizonte temático gira em torno de uma percepção dos conceitos de "eticidade" e "espírito objetivo" em que concorrem elementos provenientes do pragmatismo e da discussão do sofrimento social tal como elaborada, em geral, pelos expoentes da teoria crítica da sociedade. O conceito de "espírito objetivo" contém, para Honneth, "a tese de que toda realidade social possui uma estrutura racional, diante da qual se devem evitar conceitos falsos ou insuficientes que levem a consequências negativas no interior da própria vida social, uma vez que essas encontram aí uma aplicação prática... Hegel quer afirmar com sua representação da sociedade como "espírito objetivo" que a violação contra argumentos racionais, com os quais nossas práticas sociais sempre se encontram entrelaçadas num determinado tempo, causa dano e lesões à realidade social" (HONNETH, 2007, p. 51-52). Daí porque a violação dos fundamentos racionais que permeiam a realidade social não pode ocorrer sem consequências deletérias para a relação a si dos participantes da interação, isto é, "consequências práticas que refletem um sofrimento de indeterminação" (Idem, p. 79). Por outro lado, em sua crítica à moral deontológica, Hegel opera, sob o título de "eticidade", com a tese de que "na realidade social, ao menos na modernidade, encontram-se dispostas esferas de ação nas quais inclinações e normas morais, interesses e valores já se misturaram anteriormente em formas de interações institucionalizadas" (Idem, p. 52). Com essa ideia, Hegel se torna capaz de objetar a Kant, num paralelo à sua crítica ao "vestígio mentalista da teoria kantiana do conhecimento" (Idem, p. 93), a abstração procedimental da síntese prática prévia entre dever e inclinação, que marca a relação moral do indivíduo com a sociedade.

relacione às nossas conviç̧ões éticas em conjunto, assumiria um ponto de vista do qual, segundo Hegel, nós não dispomos quando argumentamos eticamente" (Idem, p. 296). 
Com essas teses epistemológicas ou ontológico-sociais de uma realidade social como incorporação da razão (Idem, p. 95), Hegel se permite ver, sustenta Honneth em forte proximidade com o conceito de "segunda natureza" discutido por McDowell, "uma racionalidade suficiente que já se manifestou em nossas mentalidades e tradições, em nossas normas e valores, para podermos aceitá-las como um contexto social cujas prerrogativas morais temos de pressupor geralmente como indubitáveis" (Idem, p. 96-97). Mais recentemente, Pippin parece consolidar esta diretriz ao defender uma interpretação da noção hegeliana de "racionalidade objetiva" que conduz a uma revogação da "perspectiva pré-institucional" (PIPPIN, 2008, p. 262). "O que Hegel pretende por racionalidade objetiva não pode, portanto, ser interpretado como pretensões por um tipo indireto de racionalidade subjetiva, como se racionalidade desembocasse "naquilo que agentes racionais capazes de escolha iriam querer", ou "naquilo que compreenderia as condições objetivas necessárias para a atualização do livre agir. Hegel parece ter em mente um sentido mais robusto de racionalidade genuinamente objetiva" (Idem).

Tentarei aqui explicitar, à luz dessas indicações, as motivações e decorrências do que me parece a tese central da Filosofia do Direito de $\mathrm{Hegel}^{2}$, a saber: sua profunda ligação entre uma teoria especificamente moderna da normatividade e uma teoria das instituições correspondente à concretização desta normatividade, um componente através do qual a teoria do direito revela seus contornos em termos de uma teoria social e, na verdade, também de uma ontologia social.

\section{Liberdade e Modernidade}

Hegel entende que o desafio a ser enfrentado por seu esforço filosófico consiste em corresponder à dinâmica da própria modernidade com uma teoria acerca de seu principal emblema: a liberdade, mas pensada em suas dimensões subjetiva e objetiva, normativa e institucional. A tese mais geral defendida por Hegel consiste em sustentar que a modernidade não compreende apropriadamente sua principal reivindicação, mesmo quando, tal como em Rousseau, Kant e Fichte, a liberdade é entendida como autodeterminação. Talvez por isso seja um excelente ponto de partida para a

\footnotetext{
2 Todos os trechos citados aqui da Filosofia do Direito de Hegel, embora venham indicadas conforme paginação da edição proposta pela editora Suhrkamp, são resultantes da tradução do prof. Dr. Marcos Lutz Müller, da Universidade de Campinas, Brasil. Esta excelente tradução se encontra atualmente em fase de publicação.
} 
interpretação do texto da Introdução à Filosofia do Direito entendê-lo como tentativa de superar as aporias em que se precipita a concepção moderna da liberdade como autodeterminação subjetiva.

É interessante perceber como Hegel parece orientar sua reflexão introdutória acerca da liberdade de maneira a se livrar de certas consequências - também práticas, como veremos - oriundas da "ficção gramatical da identidade",3, a qual submete a dinâmica da autodeterminação a uma frenagem, confundindo a liberdade com uma propriedade de um sujeito idêntico a si mesmo, a vontade. Segundo "esse antigo modo de proceder do conhecimento", pressupõe-se "a representação (Vorstellung) da vontade e se tentava extrair daquela uma definição da vontade fixando-a" (HEGEL, 1970, 7, p. 47). Afastando-se disso, para Hegel, "a dedução (Deduktion) de que a vontade é livre e do que seja a vontade e a liberdade

\footnotetext{
${ }^{3}$ Eu estou me referindo aqui à forma como Hegel, a seu modo e no contexto particular que estou considerando, antecipa um tema que se tornou proeminente na filosofia pós-hegeliana graças a Wittgenstein, mas não exclusivamente a ele. Por exemplo, entre os parágrafos 109 e 133 das Philosophische Untersuchungen Wittgenstein discute o problema das grammatische Täuschungen em forte conexão com sua compreensão de terapia filosófica. "Não há um método da filosofia, mas sim métodos, como que diferentes terapias." (WITTGENSTEIN, 1984, 1, p. 305) 0 desiderato por uma "visão panorâmica do uso de nossas palavras" (Idem, 1, p. 302) condiz com a ideia de que a "filosofia é uma luta contra o enfeitiçamento (Verhexung) de nosso entendimento pelos meios de nossa linguagem" (WITTGENSTEIN, 1984, 1, p. 299). "Os problemas que nascem de uma má interpretação de nossas formas linguísticas tem o caráter da profundidade. São inquietações profundas; estão enraizadas tão profundamente em nós quanto as formas de nossa linguagem, e sua importância é tão grande como a de nossa linguagem" (Idem, 1, p. p. 299). Ora, em vista disso, pensa Wittgenstein, "nós reconduzimos as palavras do seu emprego metafísico para seu emprego metafísico" (Idem, 1, p. 300). Certamente, Wittgenstein não é o único filósofo de relevo a perceber esta tendência ao aprisionamento, induzido gramaticalmente, na hipóstase, na substancialização, no esquecimento metafísico da especificidade dos jogos, chegando mesmo, como mencionado, a perceber algo como os efeitos societários e psíquicos dos jogos transpostos e hipostasiados, dado o enraizamento tão profundo em nós dessas inquietações, paralelo ao enraizamento em nós de nossa própria linguagem. "Todo conceito surge pelo pôr-como-igual do não-igual (Gleichsetzen des Nicht-Gleichen)" (NIETZSCHE, KSA, 1, p. 878-9). A linguagem tem sua origem num "esquecer-se do diferenciável" (Idem, op. cit., p. 880) que desencadeia, como discurso metafísico, a forte tendência realista do essencialismo estático, a ficção gramatical da pré-existência do idêntico em relação ao diferenciável, a não visualização do caráter "antropomórfico" da separação entre universal e singular (Idem, 1, p. 880). Tais temas, na medida em que associam, por direções diversas, um elemento filosófico-linguístico à crítica da metafísica essencialista, aproximam Nietzsche de Hegel. As primeiras reflexões de Nietzsche sobre a linguagem permanecem diretivas para seu pensamento posterior (Idem, 5, p. 12), por exemplo, a ideia de que uma crítica radical da metafísica adquire, por vezes, a feição de um autodesmascaramento da linguagem. Em Além de Bem e Mal, Nietzsche pensa que, "para constituir o alicerce das sublimes e absolutas construções filosofais que os dogmáticos ergueram", bastava "talvez algum jogo de palavras, alguma sedução por parte da gramática, ou temerária generalização de fatos muito estreitos, muito pessoais, demasiado humanos" (Idem, 5, p. 12). Nietzsche continua se embasando no desmascaramento da "superstição da alma... do sujeito e do eu" (Idem) como proveniente de um "hábito gramatical" (Idem, 5, p. 31) de considerar, por exemplo, a ação como proveniente do agente.
} 
pode ocorrer exclusivamente... na conexão do todo (im Zusammenhange des Ganzen)" (Idem, 7, p. 47). Nos formidáveis e muito comentados $\S \S 5-7$, fica claro - sobretudo pelas relações com os desenvolvimentos da Ciência da Lógica e a interpretação da vontade livre no momento da singularidade como sendo "o próprio conceito" (der Begriff selbst), que permanece para o entendimento, a fixação da identidade ${ }^{4}$, o "inconcebível" (das Unbegreifliche) (Idem, 7, 54), o “incompreensível” (Unfaßbares) (HEGEL, 1970, 10, p. 226) e o "indizível" (das Unsagbare) (Idem, 8, p. 70) - o que poderíamos chamar de frenagem da dinâmica da autodeterminação. Hegel é levado a estilhaçar a compreensão tradicional da liberdade da vontade como capacidade manifestada por um sujeito idêntico a si mesmo: ao contrário, "a liberdade da vontade... constitui o conceito ou a substancialidade da vontade" (Idem, 7, p. 54). Por isso, conclui Hegel,

quando se diz: a vontade é universal, a vontade se determina, exprime-se (ausdrückt) a vontade já como um sujeito ou um substrato pressuposto; mas ela não é algo acabado e universal antes do seu determinar-se e antes do suspender (Aufheben) este determinar, e antes da / idealidade deste determinar, pois ela só é vontade enquanto é esta atividade que se medeia dentro de si enquanto retorno (a)dentro de si (diese sich in sich vermittelnde Tätigkeit und Rückkehr in sich)" (HEGEL, 1970, 7, p. 54-55).

Em vista da tese de Hegel de que o "conceito concreto de liberdade" (Idem, 7, p. 55), aquele em que se faz jus à dinâmica da autodeterminação sem "reificar" a vontade, é o fundamento dos momentos abstratos e unilaterais, entende-se melhor como a filosofia prática tradicional possa ter privilegiado a concepção da liberdade da vontade como arbítrio (Idem, 7, p. 64). Hegel entende o arbítrio como contradição porque nele se acirra e radicaliza a oposição estanque entre os momentos na verdade constitutivos da liberdade da vontade, a infinitude formal da capacidade indeterminada de

\footnotetext{
${ }^{4}$ Poderíamos considerar a indicação feita por Hegel dos três lados da lógica (a abstração, a dialética e a especulação), uma indicação "antecipada e histórica" (HEGEL, 1970, 8, p. 167) - ou, poder-se-ia dizer, didática e que abstrai de que se trata de "momentos do todo lógico-real, ou seja, de todo conceito e de todo verdadeiro em geral" (Idem, 8, p. 167). Enquanto o lado abstrato corresponde ao pensar como operação do entendimento (Verstand), que fixa a determinidade subsistente para si contrapondo 0 universal ao particular, o conceito à intuição imediata (Idem, 8, p. 168), o momento dialético é "a natureza própria e verdadeira das determinações do entendimento... 0 ultrapassar sobre a determinidade isolada, e um relacionar dessa última pelo qual ela é posta em relação - embora sendo mantida em seu valor isolado... constitui pois a alma motriz do progredir científico; e é o princípio pelo qual entram no conteúdo da ciência a conexão e a necessidade imanente" (HEGEL, 1970, 8, p. 171-172)
} 
escolher (Idem, 7, p. 64), que se encontra acima dos diversos impulsos, bem como dos tipos singulares de sua satisfação e efetivação, um conteúdo apenas finito da autodeterminação. A situação da liberdade da vontade como arbítrio é uma de pretensa exterioridade dos conteúdos em relação ao eu (Idem, 7, p. 64) e, por conseguinte, uma de paradoxal contingência, uma vez que tanto se pretende indeterminado por conteúdos singulares quanto tem o conteúdo extrínseco como necessário. "O arbítrio... é a vontade como contradição" (Idem, 7, p. 65), o paradoxo de um conteúdo contingente, mas necessário.

Eis por que, em vista da separação estanque entre forma e conteúdo, subjetividade e objetividade, indeterminação e determinação, Hegel associa o arbítrio a uma posição dogmática, centrada numa autodeterminação puramente subjetiva ${ }^{5}$, que sucumbe com rara facilidade às investidas do determinismo (HEGEL, 1970, 7, p. 65), bem como também com o dogmatismo empirista ${ }^{6}$, que compreende o conteúdo como "algo

\footnotetext{
5 "A reflexão, a universalidade e a unidade formais da autoconsciência, é a certeza abstrata que a vontade tem de sua liberdade, mas ela não é, ainda, a verdade da liberdade, porque ela ainda não tem a si mesma por conteúdo e fim e, portanto, o lado subjetivo é ainda outro que o lado objetivo; por isso, 0 conteúdo dessa autodeterminação permanece, também, pura e simplesmente, algo apenas finito." (HEGEL, 1970, 7, p. 65).

${ }^{6}$ Aproveitando a aproximação proposta por Hegel entre sua radicalização não-representacionalista da crítica kantiana ao empirismo e o conceito de liberdade, lembramos que, numa célebre sentença no Naturrechtsaufsatz, Hegel sustenta que "uma liberdade para a qual houvesse algo realmente exterior e estranho, não é nenhuma liberdade: a essência dela e sua definição formal é, justamente, que nada há de absolutamente exterior" (HEGEL, 1970, 2, p. 476). A solução hegeliana para a cisão representacionalista entre forma e conteúdo é a visualização dialética de sua originária coabitação. $A$ dialética especulativa espera, deste ponto de vista epistemológico, "entender as estruturas holísticas atravessando os momentos, começando com concepções das coisas como são imediatamente ou em si mesmas, movendo-se em seguida à captação das mesmas como o que são mediadas ou para outros, e então para entender o que elas são em si mesmas como constituídas pelo que são para outros, enquanto imediatidade mediada" (BRANDOM, 2002, p. 209). Neste sentido, pensa Brandom, a compreensão hegeliana do conteúdo proposicional e conceitual em termos inferenciais indica uma dependência essencial do conteúdo de um juízo em relação às conexões inferenciais com outros conteúdos de possíveis juízos. Como sempre, em Hegel, tal visualização conduz, por uma "fundamentação regressiva", a uma reinterpretação, à luz da coabitação originária, de ambos os polos isolados (HEGEL, 1970, 8, p. 187). Com efeito, o projeto hegeliano conecta a natureza inferencial da experiência humana, a estruturação e sedimentação linguística desta experiência, bem como a necessidade de reinterpretar, à luz destes elementos, os polos isolados e tradicionalmente compreendidos como "forma lógica pura" e "conteúdo não-conceitual", em direção ao conceito hegeliano de "Conceito", "o grande sistema holístico, inferencialmente articulado, de conceitos determinados e de juízos articulados por aqueles conceitos" (BRANDOM, 2002, p. 224). Poderíamos dizer que Brandom e McDowell desenvolvem duas implicações possíveis, desde sempre assaz hegelianas, da "assimilação", empreendida por Wilfrid Sellars (REDDING, 2007, cap. 1 e 2), de Hegel para filosofia analítica. Sellars pretende, em suma, um resgate de Hegel com o intuito de resolver as aporias da filosofia analítica com respeito ao que chama, recuperando Russell, de "mito do dado" (REDDING, 2007, p. 29) (SELLARS, 1997, 13 e seg). De fato, o resíduo de um dado não conceitual, proveniente inexoravelmente de "fora",
} 
previamente encontrado" (HEGEL, 1970, 7, p. 65). Mas, a partir dessa associação, seria lícito entender tais insuficiências teóricas como expressões epistemológicas de posturas práticas unilaterais, ou seja, manifestações, ao nível da teoria do conhecimento, do ideário desenvolvido em torno da "autoatividade formal" (Idem, 7, p. 66). O arbítrio (Willkür), que implica na "indeterminidade do eu e na determinidade de um conteúdo" (Idem, 7, p. 66), não apenas é a compreensão "mais usual que se tem a respeito da liberdade" (Idem, 7, p. 65), mas, por isso mesmo, a liberdade da vontade em sua inverdade 7 , "na qual não se encontra nenhum pressentimento do que seja vontade livre em si e para si, o direito e a eticidade" (Idem, 7, p. 65). Isso ocorre, sugere Hegel, porque, "se eu quero o que é racional, não ajo enquanto indivíduo particular, mas, sim, segundo os conceitos de uma eticidade em geral: numa ação ética faço valer não a mim mesmo, mas a Coisa... O racional é a estrada principal, na qual cada um anda, na qual ninguém se distingue" (Idem, 7, p. 66) Por não ser capaz de penetrar nas minúcias de uma autodeterminação imanente sempre em jogo na eticidade em geral, em mundos da vida concretos (PIPPIN, 2008, p. 262), a liberdade da vontade como arbítrio condensa, em termos de conceitos práticos, a má infinitude (HEGEL, 1970, 7, p. 67), eternamente insatisfeita com a simples finitude da determinação, com seu caráter por princípio inapropriado à pureza da forma, má infinitude esta que desencadeia, mormente numa modernidade induzida aos processos de autocertificação e autojustificação,

caracteriza, para Hegel, a "não-liberdade" do empirismo e o subjetivismo ou representacionalismo da epistemologia de Kant, resultados que podem ser descritos, de maneira geral, como decorrentes de uma diferença absoluta de forma e conteúdo. Poderíamos entender Brandom (ROCKMORE, 2005, p. 165 e segs.) e McDowell (NUZZO, 2010, 96 e 158) como correspondendo ao desideratum de uma reinterpretação, respectivamente, do "mito do logicamente dado" (REDDING, 2007, 21) e do "mito do perceptivamente dado" (Idem, p. 56). Inserindo-se num ensejo criado pelo próprio Hume, ao mencionar o exemplo do "matiz de azul" como um "fenômeno contraditório que talvez prove não ser de todo impossivel que uma ideia surja sem a correspondente impressão" (HUME, 2007, 14 e seg.) - exemplo cujas consequências plenas são sistematizadas por Kant sob o título de Antizipationen der Wahrnehmung (KANT, 1968, III, p. 153) -, McDowell promove uma discussão em torno do conteúdo não-conceitual da experiência de percepção de cores, discussão que se processa no sentido de repensar a diferenciação categórica (Idem, III, p. 74) entre conceito e intuição fora do representacionalismo atomista (BRANDOM, 1994, p. 93), e que conduziu, inclusive, a uma visualização da noção hegeliana de negação determinada (REDDING, 2007, p. 22). Por outro lado, em sua revisão hegelianamente inspirada da conceitualidade da experiência, Brandom retoma, no ambiente analítico de discussão, uma tendência pós-kantiana, mas na intenção de desenvolver a "forma pura" como uma teoria holista e inferencial do conteúdo semântico (BRANDOM, 1994) (REDDING, 2007, p. 57 e segs), (ROCKMORE, 2005, 163 e segs), (NUZZO, 2010, p. 158 e segs).

7 "Se na consideração [da liberdade] se fica no arbítrio, no fato de que o homem possa fazer isto ou aquilo, isso é, sem dúvida, a sua liberdade, porém se tomamos firmemente em consideração que 0 conteúdo é dado, então o homem será por ele determinado e, nessa perspectiva, precisamente, não é mais livre" (HEGEL, 1970, 7, p. 67). 
a alternância tediosa das adesões conteudísticas, um processo no qual, por afetar estruturalmente o sentido ético, institucional e compartilhado das ações, bem que poderia ser interpretado como uma das facetas do "sofrimento de indeterminação".

A questão que me parece essencial é perceber que para Hegel a unilateralidade e o subjetivismo, constitutivos da autocompreensão da modernidade (HABERMAS, 1988, p. 38 e seg), da percepção que a filosofia moderna tem de seu paradigma de justificação ${ }^{9}$, não se pronunciam

8 Entendo por essa expressão aquela perspectiva através da qual Honneth procura ver, na Filosofia do Direito de Hegel, uma conexão entre teoria da justiça e teoria crítica da sociedade. Trata-se de pensar uma teoria da justiça cujo programa esteja centrado na proteção daqueles tecidos sociais, potencialmente incorporados nas práticas intersubjetivamente mediadas, imprescindíveis à plena efetivação da liberdade do indivíduo. Neste sentido, a "inspiração" hegeliana residira na perspectiva ascendente, que parte da tessitura de práticas sociais definidas pelo próprio mundo social moderno, perscrutando, assim, o potencial das mesmas para a realização da liberdade; ao mesmo tempo em que, através de um aclaramento acerca dos riscos de um desenvolvimento patológico destas estruturas, obtém-se um quadro normativo criterioso para aferir a saúde das práticas sociais atuais. Neste diagrama fica delineada a conexão interna, que Honneth quer tornar profícua ao pensamento político atual, entre a teoria da justiça e o diagnóstico de época (HONNETH, 2007, p. 77 e seg). Trata-se, portanto, de uma perspectiva que, inspirada no núcleo normativo proposto pelo conceito hegeliano de espírito objetivo, pauta-se pela reconstrução, a partir da necessária ancoragem das possibilidades de autorrealização individual nas instituições existentes, dos elementos normativos de uma concepção de justiça, desde já atrelada à condição de fomentar concretamente uma individualização bem-sucedida. A "Filosofia do Direito hegeliana... como projeto de uma teoria normativa, tem de ser concebida em relação àquelas esferas de reconhecimento recíproco cuja manutenção é constitutiva para a identidade moral de sociedades modernas" (Idem, p. 51). Ora, na medida em que a esta compreensão se liga necessariamente a percepção de que o mundo social moderno, cuja compreensão normativa é empreendida pelo conceito de eticidade, alinhava, em suas instituições e práticas, deveres, direitos e motivações que ou já são racionais, ou têm o potencial para tanto, é lícito afirmar que a interpretação proposta por Honneth do conceito de espírito objetivo é, na verdade, o ponto nevrálgico de sua reatualização. Por conseguinte, o "sofrimento de indeterminação" é a patologia estrutural que acomete os agentes modernos graças ao fato de que os sistemas deficientes de ação e racionalidade que tem de cotidianamente acionar tendem a desconectá-los dos contextos concretos de motivação.

${ }_{9}$ Hegel parece entender o "sofrimento social", o rastro prático ocasionado pelo embasamento da modernidade política sobre identidade abstrata da filosofia do sujeito - um "sofrimento" que Hegel entende em geral como "necessária cisão" (HEGEL, 1970, 2, p. 20) ou, num sentido mais sócio-político, " eticidade perdida" (Idem, 7, p. 339) ou "dilaceramento da vida" (Idem, 1, 327/328) - como motivação ontológica para uma filosofia dialética, como aquilo que, em suas palavras desencadeia a "necessidade" ou "carência" (Idem, 2, p. 19) da filosofia. Assim, a reflexão filosófica é reconhecida no nível epistemológico como um lado do conhecimento especulativo, assim como, no âmbito ontológico, a nãoidentidade obtém seu direito como um lado da realidade absoluta: "pois a cisão necessária é um fator da vida, que se forma eternamente pondo oposições, e a totalidade na suprema vitalidade só é possível através do [seu] restabelecimento a partir da suprema separação (Trennung)" (Idem, 2, p. 20) De fato, uma tal equação não é tão estranha ao Hegel da maturidade, bastando para isso que se veja uma de suas mais interessantes colocações na abertura da Ciência da Lógica de 1831: "a carência por compreender a lógica num sentido mais profundo do que aquele da ciência do pensar simplesmente formal é ocasionada pelo interesse da religião, do estado, do direito e da eticidade" (Idem, 8, p. 70). E Hegel completa essa ideia com a tese de que, quanto mais o pensamento abstrato se insinuou na 
apenas do ponto de visto epistemológico e ontológico, mas também se deixam perseguir no rastro de seus efeitos e tendências inscritos na realidade social (HONNETH, 2008, p. 393), nas práticas compartilhadas, "reconhecidas", incorporadas em instituições, compreendidas aqui em sentido bastante amplo. Para Hegel, a consciência universal, na qual os singulares reaparecem numa união amalgamada pelo conhecimento afirmativo e recíproco de si no outro, constitui "a forma da consciência da substância de toda espiritualidade essencial (die Form des Bewusstseins der Substanz jeder wesentlichen Geistigkeit)" (HEGEL 1995, §436). O resultado do processo de reconhecimento recíproco é este "aparecer do substancial" (Erscheinen des Substantiellen), o "vir a ser fenômeno" do elemento "espiritual" no seu ser-aí. Na fórmula que designa o "verdadeiro

realidade social, tanto mais "resultou, contudo, que as mais elevadas relações na vida foram comprometidas por isso. Por meio do pensar foi tirada do positivo sua potência" (Idem, 8, p. 70). Por mais que os autores mais recentes da teoria crítica, como Habermas e Honneth, tenham, em geral, um encaminhamento teórico não explicitamente dialético, há que se perceber, sem dúvida, a dívida que mantém com essa postura hegeliana de associar, ao conceber a relação interna entre racionalidade e realidade social, pensar a motivação ontológica da teoria crítica como sendo uma proveniente da dimensão do sofrimento social. "A "reflexão" abandonada a si mesma deixa as totalidades orgânicas desunidas ruírem nas suas partes isoladas. Ela desfaz as relações intersubjetivas transformando-as em consequências da ação, observada reciprocamente, de atores que decidem conforme fins racionais, de tal modo que os indivíduos isolados são cortados das raízes das suas procedências comuns" (HABERMAS, 2001, p. 174). 0 escopo geral de uma teoria da modernização ressurge aqui aferível em termos da tessitura simbolicamente mediada da intersubjetividade social. Sendo assim, poderíamos dizer, aproveitando a interpretação por Habermas da dinâmica crítica da sociedade capitalista como desencadeada, em Hegel e Marx, pela "dialética entre sistema e eticidade" (HABERMAS, 2012, p. 592), que Habermas procura preservar o potencial crítico pela reconstrução da normatividade, suscitada pelas rupturas do tecido simbólico, na perspectiva dos participantes dos jogos de linguagem pelos quais se reproduz um mundo da vida em processo de modernização.

10 "A ideia mestra, que anima e estrutura a lógica e a metafísica de Hegel, é sua maneira de desenvolver, de acordo com o modelo de autoridade recíproca e responsabilidade cujo paradigma é o reconhecimento recíproco, o insight de Kant-Rousseau acerca do tipo fundamental de normatividade baseada na autonomia" (BRANDOM, 2002, p. 234). Se, de fato, há que se respaldar esta posição defendida por Brandom, certamente ela não é capaz de contar toda a história com respeito a Hegel. Aquilo em que Hegel propriamente se distancia do paradigma de racionalidade criado pelas filosofias da autonomia é a definição da contrapartida institucional dos processos de justificação. Acerca do entrelaçamento entre os processos históricos pelos quais a modernidade se impôs, por um lado, e a gênese da filosofia moderna, Hegel diz: "o pensamento se fez vigente na efetividade e exerceu a mais prodigiosa eficácia. Através disso, chamou-se atenção para o poder do pensar e se começou a investigar mais de perto suas reivindicações; tencionou-se, então, ter descoberto que ele [o pensar] tinha pretensões em demasia, mas não lograva realizar aquilo que empreendia. Ao invés da essência de Deus, da natureza e do espírito - ao invés, em geral, de conhecer a verdade, ele mesmo pôs abaixo a religião e o estado. Foi exigida do pensamento uma justificação (Rechtfertigung) acerca de seus resultados, e a investigação acerca da natureza do pensamento e da sua legitimação (Berechtigung) é o que, nos tempos modernos, tem constituído em grande parte o interesse da filosofia" (HEGEL, 1970, 1, p. 70). Hegel concebe, portanto, paralelamente os processos de legitimação e de justificação dos resultados da atuação do pensamento sobre a realidade efetiva. 
conceito de consciência-de-si", “o eu que é um nós, e o nós que é eu”, o qual marca o surgimento fenomenológico do espírito, trata-se do "âmbito do normativo, enquanto produzido pelos processos de reconhecimento mútuo" (BRANDOM, 2002, p. 222). Ao conceber a liberdade positiva enquanto concretizada pelo ser-reconhecido, e não simplesmente como autodeterminação da vontade individual, Hegel está, na verdade, honrando uma intuição de juventude - "a mais elevada comunidade é a mais elevada liberdade, tanto segundo o poder, quanto segundo a execução" (HEGEL, 1970,2 , p. 82) - e, ao mesmo tempo, introduzindo a forma da base institucional, ou seja, o modo consciente, reflexivo, potencialmente moderno que tem de servir como sua mediação adequada: "A liberdade, configurada em efetividade de um mundo, recebe a forma da necessidade, cuja conexão substancial é o sistema das determinações da liberdade, e cuja conexão fenomênica é como poder (Macht), o ser-reconhecido, isto é, seu vigorar na consciência" (HEGEL, 1970, 8, p. 302). Tal resultado é da mais alta importância, principalmente se tivermos em vista o alcance da crítica hegeliana às concepções limitadas da liberdade individual através do conceito de vontade livre em-si-e-para-si (Idem, 7, §§7, p. 21; HONNETH, 2007, p. 77 e ss). Portanto, o esforço de Hegel se deixa apreender como tentativa de retomar o conceito kantiano-rousseauísta de liberdade como autodeterminação, compreendendo-o no quadro geral do problema aristotélico das condições societárias de auto-atualização.

De uma maneira mais ou menos explícita, parece-me que Hegel associa, na introdução à Filosofia do Direito, a concepção unilateral de liberdade, cuja mais abstrata formulação conceitual corresponde às aporias do arbítrio pensado a partir da autodeterminação subjetiva, a "efeitos" práticos na modernidade que poderíamos interpretar à luz das noções mais enfaticamente pós-hegelianas de "dialética do esclarecimento", "reificação", "estranhamento" e "dominação". No $\S 5$, no qual inicia sua exposição visando a uma concepção não reificada da relação entre liberdade e vontade, que se consuma numa interpretação dialética da noção kantianorousseauísta de autodeterminação (§ 7), Hegel sugere os efeitos deletérios decorrentes da fixação tipicamente moderna pelo momento da liberdade negativa, pela capacidade modernamente apreciada de indeterminar-se, de fazer de si mesmo tabula rasa. É verdade que esta capacidade, compreendida como emblema moderno favorecido pelo "puro pensamento de si mesmo" (HEGEL, 1970, 7, p. 48) e pela "liberdade negativa ou... liberdade do entendimento" (Idem, 7, p. 49) se torna praticamente uma condição de possibilidade das contestações revolucionárias, mas também a manifestação da perene e fanática aversão a qualquer forma institucional 
concreta de vida. Eis por que, acerca do período do terror na revolução francesa, Hegel diz que "significou um estremecimento, um terremoto, uma incompatibilidade com todo particular, pois o fanatismo quer algo abstrato, não quer articulação (Gliederung) alguma: onde emergem diferenças, julgaas contrárias à sua indeterminidade e suprime-as" (Idem, 7, p. 51). A noção hegeliana de liberdade negativa é suficientemente ampla para abrigar diversos filosofemas desenvolvidos na modernidade ou fora dela, e embora Kant e Rousseau sejam para Hegel teóricos comprometidos com a noção de liberdade como autodeterminação, sua fixação subjetivista da autodeterminação faz com que reverbere em seus esforços teóricos, de acordo com Hegel, algo dos efeitos práticos deletérios de uma redução da liberdade ao seu momento negativo, subjetivo, à pura indeterminidade. Hegel vê este efeito sobretudo numa concepção eminentemente coercitiva e restritiva do direito. Assim, após retomar a definição kantiana de direito como consumação da redução individualista da concepção rousseauísta de autodeteminação (HEGEL, 1970, 7, p. 79-80), Hegel completa dizendo que "esse ponto de vista está desprovido de todo pensamento especulativo e é rejeitado pelo conceito filosófico, porquanto ele produziu, nas cabeças e na efetividade, fenômenos, cujo horror só tem paralelo na trivialidade dos pensamentos nos quais se fundavam" (Idem, 7, p. 80).

Entretanto, uma das decorrências mais deletérias em termos práticos da fixação moderna sobre o momento abstrato da liberdade - e mesmo da redução subjetivista da noção de autodeterminação - é a tendência de atribuição aos "impulsos, desejos e inclinações" (Idem, 7, p. 61) um caráter em si patológico. "Esse conteúdo, junto com as suas determinações desenvolvidas, provém, na verdade, da racionalidade da vontade e, assim, ele é em si racional, mas, deixado em tal forma da imediatez, ele não está ainda na forma da racionalidade" (Idem). Implícita na resistência de Hegel a sucumbir ao lugar comum moderno no tratamento da vontade imediata ou natural (Idem) está, como decorrência da tese acerca da natureza em si racional dos impulsos, a ideia do potencial racional dos impulsos, da eticidade como um estar perpassado dos conteúdos imediatos pela forma da racionalidade. Nesse sentido, Hegel parece sustentar, com sua defesa da objetividade racional dos impulsos e de sua racionalidade em si, não a ideia de uma ontologia das pulsões, mas antes a ideia de que eticidade e liberdade terão a ver com uma penetração recíproca da estrutura pulsional dos sujeitos e dos processos de legitimação racional. "Conteúdo dos impulsos e das inclinações surge posteriormente como deveres e direitos - deveres para o sujeito, direitos em si e para si. Seu conteúdo se faz vigente" (Idem). Diante disso, torna-se mais claro porque a liberdade como contradição, manifestada no arbítrio, forma consumada da fixação subjetivista da autodeterminação, 
enreda-se numa forma específica de má infinitude que Hegel caracteriza como "dialética dos impulsos e inclinações", a qual, segundo Hegel, se manifesta no

fato de que eles se estorvam reciprocamente, a satisfação de um exigindo a subordinação ou o sacrifício da satisfação do outro etc. (...) segue-se que este determinar que subordina ou sacrifica [um ao outro] é o decidir contingente do arbítrio, [e que] proceda ele aí com um entendimento que calcula em qual impulso pode se obter mais satisfação, ou segundo qualquer outra consideração (HEGEL, 1970, 7, p. 67).

Nessas formidáveis e ricas colocações, denuncia-se num "fenômeno" (HEGEL, 1970, 7, p. 67), numa manifestação, numa sintomatologia ética, a contradição que é o arbítrio: a relação opressiva e sacrificial estabelecida entre o eu puro e indeterminado, por um lado, e a multiplicidade de conteúdos naturais passíveis de serem escolhidos. Mais do que isso, e para além do fato de ser a própria racionalidade abstrata do entendimento calculador a instância que, por meio de sua decisão contingente, estabelece o sacrifício recíproco dos impulsos, poder-se-ia, com certa liberdade interpretativa, compreender a forma de vida social tipicamente moderna, enquanto "sistema da eticidade perdida em seus extremos" (System der in ihre Extreme verlorenen Sittlichkeit) (Idem, 7, p. 339), como se manifestando eticamente nessa sintomatologia, ou seja, numa atitude sistematicamente sacrificial dos indivíduos para com suas próprias estruturas pulsionais ${ }^{11}$. Assim, numa forma de vida para a qual a liberdade formal do arbítrio se tornou sistematicamente institucionalizada, os indivíduos mantém para com seus afetos e inclinações uma postura em geral destrutiva, ou, devido à maximização da satisfação de um em detrimento dos outros, ao menos sacrificial. "Quando então, pospondo todos os outros, me coloco num deles apenas, encontro-me, assim, numa restrição destruidora, pois, precisamente por isso, abandonei a minha universalidade, que é um sistema de todos os impulsos" (Idem, 7, p. 68). Não é difícil ver, portanto, que Hegel defende, como potencial intrínseco às formas de

\footnotetext{
${ }^{11}$ A partir dessa postura sacrifical do arbítrio, poderia sustentar a tese de que Adorno não é totalmente explícito quanto aos potenciais sócio-filosóficos da dialética hegeliana que ele próprio desenvolve no sentido de uma crítica da mesma (ADORNO, 2009, p. 13 e seg) (O'CONNOR, 2004, cap. 1 e 4), ou seja, o vínculo da teoria dialética a uma ontologia do sofrimento, do sacrifício necessário, empreendido pelo pensamento, da própria multiplicidade qualitativa da experiência. "O que há de doloroso na dialética é a dor em relação a esse mundo, elevada ao âmbito do conceito" (ADORNO, 2009, p. 14).
} 
organização institucional sob a modernidade política, não uma hieraquia qualquer dos impulsos ${ }^{12}$, mas a universalidade concreta dos mesmos, um sistema no qual as pulsões não estabeleçam uma relação reciprocamente sacrificial, sendo assim "reconduzidos à sua essência substancial" (Idem, 7, p. 69). Eis por que, pensa Hegel, o único sentido da indeterminada "exigência de purificação dos impulsos" compatível com sua interpretação dialética da autodeterminação é a libertação dos mesmos "da forma da sua determinidade natural imediata e do que há de subjetivo e contingente no conteúdo" (Idem, 7, p. 69), de maneira que o próprio "conteúdo da Ciência do Direito" pode ser descrito como a apreensão, a partir do conceito, dos impulsos como "sistema racional das determinações da vontade" (HEGEL, 1970, 7, p. 69), ou, dito de outra maneira, apreender dialeticoespeculativamente os impulsos sob "outra forma do mesmo conteúdo... a saber, a dos deveres (Pflichten)" (Idem, 7, p. 69).

\section{Modernidade e Direito}

Já foi observado, de forma muito apropriada a meu ver, que o desenvolvimento do pensamento hegeliano obstaculizou a plausibilidade da tese de que se pudesse retornar romanticamente a passados idealizados, restaurando formas de vida específicas e pré-modernas capazes de refrear as tendências destrutivas e fragmentadoras impostas pela concepção subjetiva da liberdade, e mesmo da liberdade como autodeterminação. Também é possível mostrar que o desenvolvimento teórico de Hegel se deu pela via da necessidade de equipar a compreensão subjetivista da liberdade como autodeterminação com um componente objetivista, institucional e substancialista, relativo às práticas concretas de institucionalização dos processos modernos de justificação, através da qual a própria unilateralidade se torna, na verdade, em primeiro lugar legível. Hegel empreende esta sofisticada síntese recorrendo ao componente "comunitarista" presente, por exemplo, em Platão, Aristóteles e Montesquieu. Como Hegel não deseja comprometer o alcance da concepção moderna dos processos de justificação, pensados a partir da categoria de autodeterminação, com esta síntese se torna possível pensar a normatividade moderna do ponto de vista dos processos institucionais constitutivos de

\footnotetext{
12 "Tampouco adianta uma mera subordinação dos impulsos, a que o entendimento habitualmente recorre, pois nenhuma medida desta ordenação pode aqui ser dada e a exigência de uma tal ordenação desemboca normalmente num palavrório genérico tedioso" (HEGEL, 1970, 7, p. 68).
} 
formas de vida $^{13}$, ou seja, a visualização da forma como processos especificamente modernos de legitimação se encontram ou podem se encontrar inseridos nas práticas modernas. O objetivo mais geral, poder-seia dizer, consiste em pensar, em sua complementaridade, os processos de justificação e sua concretização em práticas, explicitando, assim, o próprio sentido, socialmente relevante, em que a liberdade como autodeterminação pode ser a realização moderna da liberdade.

Alguns dos parágrafos mais célebres da introdução à Filosofia do Direito ajudam a respaldar essa leitura, na medida em que esclarecem a cientificidade, o caráter filosófico e "metodológico", do esforço contido na obra. "A ciência do Direito é uma parte da Filosofia. Por isso, [como ciência] ela tem de, a partir do conceito, desenvolver a ideia, enquanto esta é a razão de um objeto, ou, o que é o mesmo, ela tem de dirigir o seu olhar ao próprio desenvolvimento imanente da coisa mesma" (HEGEL, 1970, 7, p. 30). Naturalmente, não posso, na presente oportunidade, elucidar completamente essa relação entre a filosofia do direito e o "método dialético"14. Para falar a verdade, num dos mais célebres parágrafos da introdução à Filosofia do Direito, fica clara a compreensão da dialética ${ }^{15}$ como a transformação da concepção kantiana de autodeterminação numa teoria da objetividade, numa ontologia e numa teoria da compreensão, a qual se constitui pela relação intrínseca entre a razão objetiva e a razão subjetiva, entre substância e sujeito, de tal maneira que compreender passa a consistir na apreensão conceitual de uma miríade de práticas e conceitos compartilhados, dotados de autoridade normativa.

No presente trabalho, interessa-me principalmente chamar a atenção para o comprometimento de Hegel, mesmo na Filosofia do Direito, com um movimento de virada pragmática na ontologia, o qual prepara uma instigante $\mathrm{e}$ de múltiplas decorrências noção social de ontologia como constituída pelas práticas e conceitos compartilhados comunitariamente, elementos dotados de

\footnotetext{
${ }^{13}$ Pippin tem uma compreensão muito instigante dessa "racionalidade objetiva da ordem social, a ordem que incorpora a pretensão a autoridade normativa de uma maneira consistente com a única origem possível de tal autoridade: agentes livres, racionalmente autodeterminantes em relações inevitáveis de reconhecimento recíproco" (PIPPIN, 2008, p. 236).

${ }^{14} \mathrm{~A}$ esse propósito me parece convir perfeitamente 0 alentado e inspirador esforço de Klaus Vieweg (VIEWEG, 2014).

15 "A dialética superior do conceito não consiste em produzir e apreender a determinação meramente como barreira e como contrário, mas, sim, em produzir e apreender a partir dela 0 conteúdo e 0 resultado positivos, enquanto por essa via, unicamente, a dialética é desenvolvimento e progredir imanente... / Considerar algo racionalmente não significa acrescentar de fora uma razão ao ob-jeto e, por este intermédio, elaborá-lo, senão que o ob-jeto é por si mesmo racional; aqui é o espírito na sua liberdade, o ápice da razão autoconsciente, que se dá efetividade e se gera como mundo existente; a ciência tem somente a tarefa de trazer à consciência esse trabalho próprio da razão da coisa" (HEGEL, 1970, 7, p. 83-84).
} 
autoridade normativa. Parece-me que, depois de Sellars, Pinkard foi o primeiro a chamar atenção do comprometimento de Hegel com esse paradigma. Segundo Pinkard, "o fornecimento de razões... é ele mesmo uma prática social que atua no âmbito de uma forma determinada de "espaço social", permitindo alguns tipos de inferência e falhando em permitir outras" (PINKARD, 1996, 8). Eis por que, sendo uma consideração reflexiva e autoconsciente dos padrões e normas que reivindicam legitimidade, "todas estas formas de autoconsciência tem uma estrutura mediada (isto é, inferencial)" (Idem, p. 8). Do ponto de vista históricofilosófico, a tese de uma alegada "socialidade da razão", a qual pretende que esteja em curso, na Fenomenologia, "uma teoria normativa do agir racional de indivíduos ocupando posições no interior de um "espaço social" compartilhado e governado por regras" (REDDING, 2007, p. 14), representa uma estreita relação entre Hegel e a "pragmática linguística" surgida com o último Wittgenstein. "Aquilo que nós denominamos "seguir uma regra" é algo que somente um homem, somente uma vez na vida, poderia fazer? - E isto é, naturalmente, uma observação sobre a gramática da expressão "seguir a regra"... compreender uma frase significa compreender uma linguagem. Compreender uma linguagem significa dominar uma técnica" (WITTGENSTEIN, 1984, I, p. 199). A compreensão de frases está ligada ao engajamento apropriado nas práticas que tornam significativo determinado signo, nas práticas de seu uso, as quais são incorporadas em formas de vida sócio-culturais. Compreender uma linguagem, isto é, a diversidade do entrelaçamento entre os elementos linguísticos e as práticas extralinguísticas, é adquirir competências que habilitam à participação nestas atividades regradas. $\mathrm{Na}$ linha dessa aproximação, Pippin entende o conceito hegeliano de espírito ou de "ordem normativa" como

uma questão "lógica" ou categorial sobre o natural e o normativo ou, tal como Sellars primeiro o formulou, o espaço das causas e o espaço das razões... É também verdade, portanto, que Hegel pensa os conceitos e normas funcionalmente, em termos kantianos, como predicados de juízos possíveis, e então, vai mais longe do que Kant ao ligar toda possível compreensão do conteúdo conceitual e normativo ao uso efetivo nos limites de uma comunidade linguística, orientada sensivelmente por normas ou pela emissão de juízos. Em outras palavras, enquanto a teoria mais fundamental das categorias em Hegel é uma teoria da normatividade (normas para tornar o mundo inteligível e para agir corretamente), não é uma teoria simplesmente formal, prescritiva. Conteúdo conceitual é compreendido como fixado pelo uso efetivo, de maneira que não há nenhuma separação 
"ser/dever-ser... esta interpretação requer, em última instância, que a natureza da autoridade de tais coerções normativas e ideais seja autolegislada... sob estas premissas, exercer a autoridade normativa em geral é compreendido enfaticamente como a expressão de intenção no espaço público e social, funcionando como [norma] que autoriza somente se há um contexto social suficientemente harmonioso e dotado de sentido, capaz de responder, de maneira correta, a possíveis desafios apresentados a uma tal autoridade (PIPPIN, 2008, p. 236).

Aqui basta apreender a relação entre processos de justificação e práticas compartilhadas, constitutiva dessa "ontologia social", em seus contornos gerais. Uma vez garantida a necessidade do conceito de direito através de sua dedução ou demonstração, entendida por Hegel no sentido de "seu ter vindo a ser enquanto resultado" (HEGEL, 1970, 7, p. 30), deve-se

olhar em torno aquilo que nas representações e na linguagem the corresponde. Mas o modo como este conceito é por si em sua verdade e como ele é na representação não só pode ser diverso um do outro, senão que ele têm de sê-lo, também, quanto à forma e à figura. Se, entretanto, a representação também não é falsa quanto ao seu conteúdo, o conceito pode, certamente, ser mostrado como contido nela, e, quanto à sua essência, como nela presente, isto é, a representação pode ser erguida à forma do conceito. Mas ela é tão pouco padrão de medida e critério do conceito, necessário e verdadeiro por si mesmo, que é antes ela que tem de tomar dele a sua verdade, e a partir dele corrigir-se e reconhecer-se (sich aus ihm zu berichtigen und zu erkennen). (HEGEL, 1970, 7, p. 31).

Com efeito, defende Hegel, para além (ou justamente pelo fato) de a progressão categorial na Filosofia do Direito ocorrer em ritmo dialético, a tese de que tenha como solo um conceito cuja necessidade em si e para si já foi demonstrada como objetividade espiritual apropriada à modernidade inviabiliza a linearidade de uma simples aplicação da estruturação lógica do conceito ao âmbito jurídico. Ao contrário, justamente porque o direito é o próprio conceito em seu tensionamento entre processos de autojustificação e quadros institucionais com eles condizentes, a progressão categorial da Filosofia do Direito envolve sempre a demonstração do caráter verdadeiro da representação enquanto conteúdo a partir da elevação dela, sobretudo em 
sua estruturação linguística, ao conceito, isto é, à interpenetração dos processos de justificação da normatividade e das práticas linguisticamente estruturadas e compartilhadas nas formas de vida modernas. "Aqui, é preciso pressupor, a partir da lógica filosófica, em que consiste o procedimento científico da Filosofia" (HEGEL, 1970, 7, p. 31). Assim, como veremos, a démarche dialética da ciência filosófica do direito, que faz do caráter revolucionário dos processos de modernização - compreendidos no bojo de uma conexão imanente entre práticas e justificação - o cerne da filosofia do direito, consiste em deslindar a interpenetração da autocertificação e do quando institucional, da indeterminidade e da determinação, da infinitude e da finitude.

Eis por que Hegel depreende decorrências desse programa numa reinterpretação da relação entre direito natural e positivo. Embora reconheça o estatuto de certa autonomia à "ciência positiva do direito" (Idem, 7, p. 32), na jurisdição, sobretudo no que tange a problemas de aplicação, do entendimento, Hegel defende uma relação entre direito natural e positivo que, embora difícil de apreender num primeiro momento, serve à visualização do caráter inovador de seu esforço filosófico. "Seria um grande malentendido inverter o fato de que o direito natural ou o direito filosófico é diverso do direito positivo na afirmação de que eles se opõem um ao outro e conflitam entre si” (HEGEL, 1970, 7, p. 32) Mas se não se deve nem confundi-los e nem tratá-los como absolutamente opostos, em que consiste afinal a posição de Hegel? Em nada mais senão em captá-los na sua imbricação, em sua interpenetração, ou, numa palavra, captá-los como determinações contraditórias de uma unidade, como momentos de uma totalidade concreta, direção na qual, defende Hegel, deixa-se perceber sobre ele a influência proveniente de Montesquieu,

... quem estabeleceu a verdadeira visão histórica, o legítimo ponto de vista filosófico: considerar a legislação em geral e as suas determinações particulares não isolada ou abstratamente, mas sim, muito mais como momento dependente de uma totalidade, em conexão com todas as determinações restantes que constituem o caráter de uma nação e de uma época; nessa conexão elas adquirem a sua verdadeira significação, assim como, a sua justificação (HEGEL, 1970, 7, p. 34).

Hegel deseja que sua ciência filosófica do direito possa ultrapassar, onde for possível e de forma imanente, a visada propiciada pelo entendimento acerca da explicação e justificação histórica, alcançando, a partir da tessitura prático-normativa do quadro institucional, "o significado 
de uma justificação válida em si e por si” (Idem, 7, p. 34) Por conseguinte, assumindo uma postura que me parece ainda hoje inspiradora para uma teoria crítica da sociedade, para uma teoria da modernidade, para uma filosofia social e para um teoria pragmatista da normatividade, Hegel parece defender que a justificação racional e a explicação histórica tem de ser diferenciadas enfaticamente, mas que não se pode perder sua conexão intrínseca, sua imbricação e, por conseguinte, não se pode deixar de apontar os potenciais de práticas concretas e compartilhadas para desenvolver padrões de justificação de normas que sejam condizentes com a noção de autodeterminação, à qual o pensamento de Rousseau, Kant e Fichte alçou o espírito moderno. Se um resultado direto desse programa é a ideia de que os processos tipicamente modernos de autolegitimação e justificação necessitam ser ancorados e sustentados em práticas e instituições que favoreçam seu desencadeamento ${ }^{16}$, também a esta altura começa a se delinear a verdadeira promissória a ser resgatada: para não sucumbir à dialética do esclarecimento e à perda de substancialidade pela absolutização da racionalidade subjetiva, Hegel tem de preservar teoricamente os dois momentos como interligados, pensando-os em sua unidade contraditória, para o que se faz necessário assumir o caráter em si racional dos quadros institucionais modernos, uma concepção de racionalidade objetiva que seja capaz de explicar as formas pelas quais pode provocar sobre si mesma a coerção dos processos de justificação ${ }^{17}$.

Seja como for, caso eu possa me considerar numa direção minimamente correta até este ponto, seria possível interpretar de maneira

\footnotetext{
${ }^{16}$ As ideias morais "têm que ser transformadas, como diz Hegel, em debates concretos da vida cotidiana. E assim é em realidade: toda moral universalista depende da sustentação e do apoio que lhe ofereçam as formas de vida. Necessita de certa concordância com práticas de socialização e educação que ponham em marcha nos sujeitos controles de consciência fortemente internalizados e fomentem identidades do eu relativamente abstratas. Uma moral universalista necessita também de certa concordância com instituições sociais e políticas em que já estejam encarnadas ideias jurídicas e morais de tipo pós-convencional" (HABERMAS, 1986, p. 23).

$17 \mathrm{Se}$ a crítica da modernidade sucumbe, em geral, à armadilha não-dialética de que o travamento se deve à confusão iniludível entre gênese e validade, contraditoriamente ligada à expectativa por um desmascaramento instantâneo sem a promissória de uma dimensão enfática de validade, Habermas recupera tendências da dialética anteriores à aporética da crítica totalizante, o entrelaçamento entre os contexto de sentido e o contexto factual, entre a validade e a gênese, tendências que me parecem estar prenunciadas no texto hegeliano. "[E]las precisam ser separadas pelo pensamento que faz a mediação da maneira procedural, o que significa: sempre de novo. Na argumentação, crítica e teoria, esclarecimento e fundamentação se entrelaçam continuamente, mesmo quando os participantes do discurso tem de assumir que, sob os inevitáveis pressupostos de comunicação do discurso argumentativo, somente tem vez a coação não coercitiva do melhor argumento. Mas sabem, ou poderiam saber, que também esta idealização só é necessária uma vez que as convicções se formam e se mantém em um medium que não é "puro" (HABERMAS, 2001, p. 185-186).
} 
mais intuitiva duas teses colhidas por Hegel em sua interpretação dialética da autodeterminação, tema do célebre $\S 7$, ambas as teses profundamente relacionadas à ideia de que a filosofia especulativa ousa "apreender a negatividade imanente no universal e no idêntico, como no eu", e que, por causa disso, torna-se capaz de apreender "o dualismo da infinitude e da finitude... na imanência e na abstração" (HEGEL, 1970, 7, p. 52). Primeiramente, a tese de que a autodeterminação da vontade, quando compreendida coerentemente, é, enquanto unidade dialética da indeterminação e da determinidade, o conceito como singularidade mediada consigo e em si mesma e que, sendo assim, "o concreto e verdadeiro (e todo verdadeiro é concreto) é a universalidade que tem o particular por oposto, mas um particular que pela sua reflexão dentro de si igualou-se ao universal" (Idem, 7, p. 54). Em segundo lugar, a ideia de que o "conceito concreto de liberdade" (Idem, 7, p. 56) - o qual torna claro que "a liberdade não reside... nem na indeterminidade, nem na determinidade, senão que ela é ambas" (Idem) - acha-se explicitado, ainda que como sentimento, no amor e na amizade, nos quais nem a determinação é sentida como extrínseca e, por conseguinte, também não infringe a cláusula de um acolhimento autodeterminado, assim como a indeterminidade se acomoda a uma relação intersubjetiva como condição de sua concretude: tem-se aqui um autêntico e paradigmático caso de conexão imanente entre infinitude e a finitude, entre a indeterminidade e a determinidade.

Como se pode perceber, mesmo que de forma geral, a imbricação entre justificação e práticas institucionalizadas numa perspectiva mais societária torna-se mais clara nos $\S \S 21-24$, nos quais Hegel tematiza seu conceito chave de vontade livre em si e para si, a universalidade que, enquanto forma infinita, tem-se a si mesma como objeto e fim e que constitui, como diz Hegel, "o princípio do direito, da moralidade e de toda a eticidade" (HEGEL, 1970, 7, p. 71). Interessa-me aqui sobretudo aquilo que nesse contexto pode render uma interpretação mais ético-política da má infinitude como aporia resultante da concepção insuficiente que a modernidade tem de seu próprio emblema: a liberdade.

No $\S 22$, Hegel promove uma tal reflexão, logo depois de se referir novamente à sua crítica ao problema de uma compreensão da liberdade pautado pela ficção linguística da identidade. A vontade livre em si e para si é, diz Hegel, verdadeiramente infinita e, na verdade, o infinito atual, efetivamente infinita, já que "o ser-aí do conceito, ou sua exterioridade objetual, é o interior ele mesmo" (HEGEL, 1970, 7, p. 73) Por outro lado, a 
modernidade sistematicamente retém, sob a inspiração de premissas linguístico-conceituais inconfessáveis ${ }^{18}$, essa dinâmica, essa fluidez estabelecida pela imbricação entre a infinitude e a finitude, entre o ser-aí e o conceito. O resultado disso é a fixação numa concepção de infinitude meramente potencial, incapaz de acessar a relação imanente entre finito e infinito, pensada numa compreensão do infinitum actu, uma "infinitude meramente negativa e ruim, a qual não tem, assim como a verdadeira [infinitude], o retorno adentro de si mesma. A vontade livre é verdadeiramente infinita, pois ela não é meramente uma possibilidade e disposição, mas antes seu ser-aí exterior é sua interioridade, ela mesma" (Idem). Mas como interpretar o sentido ético-político e societário da má infinitude? Do ponto de vista relevante a uma teoria da sociedade moderna, a má infinitude é resultante de uma hipertrofia da dimensão puramente subjetiva da liberdade e, como em Kant, Rousseau e Fichte, da autodeterminação. Trata-se, portanto, da formulação "lógica" do desapreço por práticas institucionalizadas determinadas, bem como uma tendência à afirmação radical de liberdade na figura da singularidade excludente. Com isso, a ideia de má infinitude congrega em si as principais unilateralidades de que é vítima a própria autocompreensão moderna da legitimidade e, por conseguinte, associa-se intimamente com os sintomas ocasionados por essa unilateralidade na vida ético-política: formas fanáticas de estranhamento do mundo institucional, uma postura em geral calculista e reducionista dos indivíduos para com seus impulsos e afetos, e uma estrutural perda da substancialidade. Por outro lado, a vontade livre em si e para si, célulatronco da filosofia hegeliana do direito, é a tentativa de vencer, do ponto de vista de uma filosofia política, de uma filosofia social e de uma teoria da justiça, essa unilateralidade, conduzindo à apreensão da imbricação entre as práticas compartilhadas e institucionalizadas, por um lado, e a forma paradigmática dos processos modernos de justificação e legitimação.

É a universalidade concreta dentro de si e, assim, sendo para si, que é a substância, o gênero imanente ou a ideia imanente da autoconsciência; - é o conceito da vontade livre como o universal que se estende sobre e abarca o seu ob-jeto, que perpassa a sua determinação, que nela é idêntico consigo. - O

\footnotetext{
18 "quando se fala somente de vontade livre como tal, sem a determinação segundo a qual ela é em si e para si vontade livre, então se fala apenas da disposição (Anlage) da liberdade, ou seja, da liberdade natural e finita, e justamente com isso, apesar das palavras e da opinião, não da vontade livre" (HEGEL, 1970, 7, p. 73).
} 
universal sendo em si e para si é, em princípio, o que se chama de racional e o que só pode ser apreendido dessa maneira especulativa. (HEGEL, 1970, 7, p. 74).

Parece-me que este itinerário retoma, de maneira extraordinária, tópicos presentes no próprio desenvolvimento intelectual de Hegel, estágios nos quais importantes filosofemas ocidentais são assimilados criticamente e combinados numa teoria abrangente da atualização prático-institucional da dinâmica moderna da justificação de normas, embasada na noção de autodeterminação. Trata-se de uma sensacional combinação da tese aristotélica da consumação sócio-política da natureza dependente, deliberativa e relacional do ser humano ${ }^{19}$, da posição rousseauísta-kantiana da liberdade como autodeterminação, da intuição de Montesquieu acerca do normativo e do institucional como momentos da totalidade concreta e da tese espinosana ${ }^{20}$ da relação imanente e substancial entre o infinito e o finito, entre sujeito e objeto, entre a indeterminação e a determinação. A minha tese acerca do ponto de vista mais geral fornecido pela Introdução à Filosofia do Direito consiste em que esse projeto ambicioso e ousado, o qual pode ser descrito como tentativa de visualizar a dinâmica social especificamente moderna em termos de uma complementaridade entre autodeterminação e atualização, é o constituinte fundamental da noção incomum, algo contraintuitiva mas prodigiosa, que Hegel tem do Direito (Recht).

A partir de tais ideias, eu gostaria de retomar alguns parágrafos da Filosofia do Direito que se debruçam especialmente sobre o conceito de direito, discutindo seus aspectos, por assim dizer, subjetivo e objetivo. "A ciência filosófica do Direito tem por ob-jeto a idéia do Direito, o conceito

\footnotetext{
19 O jovem Hegel segue um programa de uma correção "comunitarista" do direito natural moderno. A tese fundamental da política clássica de que "o positivo é, segundo a natureza, anterior ao negativo, ou, como diz Aristóteles, o povo é, segundo a natureza, anterior ao singular" (HEGEL, op. cit., vol.2, p. 505), é evocada no intuito preciso de "contrabalançar" o individualismo e atomismo da compreensão jusnaturalista da associação política. No System der Sittlichkeit, através de um resgate não simplesmente programático, como no Naturrechtsaufsatz, da tese aristotélica da "anterioridade da pólis", Hegel estabelece, em sua teoria do desenvolvimento da eticidade, a conexão entre a liberdade individual, radicalizada pela filosofia transcendental, e a formulação de um quadro institucional comunitário no qual aquela liberdade pode encontrar sua efetivação adequada, o que estabelece a feição madura de sua filosofia política.

20 O programa de um "sistema da eticidade", delineado no Naturrechtsaufsatz e levado a termo, graças ao alinhamento de Hegel à Potenzenmethode de Schelling, no System der Sittlichkeit, caracteriza-se sobretudo por uma equiparação da doutrina espinosana da substância infinita, à qual Hegel adere imediatamente depois da Seinsmetaphysik do período de Frankfurt graças à influência do projeto schellingniano de mediação entre Kant e Espinosa, com a doutrina aristotélica da comunidade política (ILTING, 1974, p. 777).
} 
do Direito e a sua efetivação" (HEGEL, 1970, 7, p. 28). Obviamente, é uma sentença imbuída das decorrências da tese de que a Lógica é o "espírito omnivivificante de todas as ciências" (der allbelebende Geist aller Wissenschaften) (Idem, 8, p. 77). Entretanto, interessa-me reter o sentido de tal ideia mais relevante para a teoria hegeliana da normatividade. Hegel sugere, no decorrer do texto, que a filosofia tem a ver sobretudo com a indicação da unilaterialidade e inverdade de "meros conceitos" (bloße Begriffe), ou seja, com a crítica de compreensões da realidade a que comumente se recorre, mas que são incapazes de pensar seu próprio lastro institucional. Mas o que mais interessa à filosofia, desvencilhando-se dos meros construtos do entendimento, é mostrar que "é o conceito... o que unicamente tem efetividade e que a tem de modo tal, que ele mesmo se dá esta efetividade" (Idem, 7, p. 29), isto é, desenvolver a teoria da normatividade conceitual capaz de abranger o pensamento de sua própria efetividade: apenas uma teoria da normatividade capaz de corresponder ao desiderato por uma apreensão de sua institucionalidade faz jus ao emblema mais sofisticado da modernidade, isto é, a liberdade como autodeterminação, como racionalidade que dá a si mesma seu conteúdo. "A configuração (Gestaltung) que o conceito se dá na sua efetivação é, para o conhecimento do próprio conceito, o outro momento essencial da ideia, diferente da forma de ser somente conceito" (Idem, 7, p. 29). Apesar de sua escandalosa sentença (que tem sido interpretada como sendo supostamente) sobre a irrelevância do ser-aí, parece-me que Hegel nesse parágrafo tenciona explicitar o escopo de uma teoria da normatividade racional que, do ponto de vista da filosofia prática, seja capaz de corresponder às mais profundas exigências postas pelas revoluções burguesas, as quais, embasadas em "meros conceitos", muitas vezes talvez não tenham conseguido se tornar conscientes disso, mas reivindicam a compreensão da interpenetração dos processos de justificação e do quadro institucional. "A unidade do ser-aí e do conceito, do corpo e da alma é a ideia. Ela é não só harmonia, mas também interpenetração perfeita (vollkommene Durchdringung)" (HEGEL, 1970, 7, p. 29). Trata-se, a um só tempo, em ritmo dialético, da compreensão da dimensão institucional, efetiva, objetiva, assim como também da dimensão subjetiva, aquela dimensão da justificação, da validade, à qual se referem Rousseau e Kant como sendo digna de uma semântica específica (BRANDOM, 2002, p. 234) e, do ponto de vista dos processos históricos pelos quais a modernidade se impôs, omniabrangente, isto é, capaz de se insinuar na compreensão das diversas práticas institucionalizadas e compartilhadas. Esta filosofia do direito, transformada em teoria social normativa, mantém com o sofisticado esforço 
rousseauísta-kantiano uma relação ambígua. $\mathrm{Na}$ medida em que revela o subjetivismo de sua concepção de autodeterminação, revela-a como mero conceito e, por isso, como unilateral; na medida em que ousa pensar a componente institucional como intrinsecamente atrelada à normatividade conceitual, faz jus, de maneira radical, à própria noção de autodeterminação, fojando um robusto conceito de liberdade: "a ideia do Direito é a liberdade, e para ser verdadeiramente apreendida, ela tem de ser conhecida no seu conceito e no seu ser-aí" (HEGEL, 1970, 7, p. 29).

Portanto, não é inteiramente verdade que o ser-aí seja desprezado. $\mathrm{O}$ problema é que, numa teoria das instituições formulada em harmonia (Harmonie) com a teoria da normatividade conceitual, ou seja, do ponto de vista filosófico, essencial como produto do desenvolvimento histórico é a "configuração", o mundo de instituições e práticas compartilhadas perpassado pelos processos modernos de justificação e validação. Assim, desenvolver a ideia a partir do conceito é lançar olhos sobre "o próprio desenvolvimento imanente da coisa mesma" (Idem, 7, p. 29), o que inclui certamente o desdobramento do conceito como efetividade, no sentido de uma normatividade conceitual forte, mas também o sentido de uma passagem das representações imediatas, das práticas institucionais constitutivas do "mundo da vida", ao conceito.

Se, entretanto, a representação também não é falsa quanto ao seu conteúdo, o conceito pode, certamente, ser mostrado como contido nela, e, quanto à sua essência, como nela presente, isto é, a representação pode ser erguida à forma do conceito. Mas ela é tão pouco padrão de medida e critério do conceito, necessário e verdadeiro por si mesmo, que é antes ela que tem de tomar dele a sua verdade, e a partir dele corrigir-se e reconhecer-se (HEGEL, 1970, 7, p. 31).

Vimos acima que do $\S 3$ provém uma exigência criada no contexto histórico moderno. Para Hegel, a modernidade força o pensamento a compreender a relação entre substância e sujeito e, no caso específico de uma teoria da justiça, a pensar a conexão espiritual do positivo e do natural, da facticidade e da validade, sem que se deva assumir nem a postura resignada do "positivismo jurídico", nem o abstracionismo dos teóricos do dever-ser e da infinitude ruim, os entusiastas dos processos puros de legitimação de normas. O risco no primeiro caso é aquele de preservar excessivamente a tradição, perdendo a dimensão da validade. $\mathrm{O}$ risco no segundo caso é por em marcha, de maneira ainda mais exasperada, a dialética do esclarecimento e a perda pela subjetividade de sua substancialidade. "O solo do Direito é, em geral, o [elemento] espiritual" 
(HEGEL, 1970, 7, p. 45). O ponto de partida é, portanto, para Hegel, uma interpretação da síntese que ele pensa ter sido proposta por Montesquieu do natural e do positivo como constitutiva de sua noção de espírito, concebido então, de acordo com os desenvolvimentos anteriores, como um conjunto de práticas compartilhadas, consolidadas ou não em instituições, sob a pressão constante dos processos de legitimação que se insinuam mais fortemente no mundo das ações com a formação da modernidade política.

Este entrelaçamento, consitutivo do espírito, é o ambiente no qual o direito, em sua acepção especificamente hegeliana, terá seu desenvolvimento imanente. Este ambiente é dinamizado pela assimilação do desenvolvimento teórico moderno nos processos de legitimação: "seu [do Direito] lugar mais preciso e o seu ponto de partida [é] a vontade que é livre" (Idem, 7, p. 45). Os $\S \S 5,6$ e 7 mostrarão como Hegel pretende fazer isso, ou seja, a partir do argumento de que o conceito rousseauísta-kantiano de autodeterminação conduz, caso seja compreendido de forma consistente, à tese especulativa de que "a liberdade constitui a sua substância e a sua destinação" (Idem, 7, p. 45). Assim, ao estabelecer a liberdade não apenas como estruturação substancial da vontade livre, conexão imanente de seus momentos positivo e negativo, finito e infinito, factual e legítimo, mas também como seu fim, sua destinação, seu objeto, seu mundo, Hegel propõe uma teoria do direito que rompe com a tendência formalista de um abstracionismo institucional $^{21}$, unindo à teoria do direito, ao contrário, uma teoria da justiça, e à filosofia política, uma teoria social normativa. Trata-se, do ponto de vista dos potenciais para uma crítica da sociedade moderna, de uma teoria na qual, devido à relação pensada dialeticamente entre razão subjetiva e razão objetiva, a modernidade pode ser visualizada, por

\footnotetext{
${ }^{21}$ Honneth toma de Hegel um conceito intersubjetivista de liberdade individual que focaliza a tessitura de interações unicamente capazes de efetivar a liberdade do indivíduo. Assim, recuperando algo das críticas do "comunitarismo" ao liberalismo (FORST, 1995), mas sem renunciar às bases normativas de uma concepção de justiça alheia ao relativismo, Honneth formula uma teoria da justiça que, contrapondo-se a Rawls, pretende neutralizar aquele expediente "abstracionista", proveniente da tradição kantiana e que se consuma na pretensão de uma dedução do quadro institucional prioritariamente partir de princípios. Tal "dedução" de um quadro institucional faria, de acordo com Hegel, abstração do contexto. Honneth propõe a reconstrução, a partir da necessária ancoragem das possibilidades de autorrealização individual nas instituições existentes, dos elementos normativos de uma concepção de justiça, desde já atrelada à condição de fomentar concretamente uma individualização bem-sucedida, contrapondo-se à compreensão da relação entre os princípios justiça e os "bens básicos" em Rawls e, por conseguinte, fazendo da "reconstrução normativa" uma alternativa ao construtivismo de extração kantiana: as interações formativas não são somente um bem básico, mas a própria concepção moderna de justiça se vincula à ideia de possibilitar, no tecido formado pela prática comunicativa, a plena autorrealização individual (HONNETH, op. cit., p. 63, 131, p. 140).
} 
exemplo, no processo de corrosão da eticidade, legível institucionalmente, desencadeado pela absolutização da razão subjetiva.

Sistematizando nossas observações, podemos distinguir esquematicamente cinco dimensões contidas neste programa: uma teoria da normatividade conceitual, uma teoria da justiça como dimensão correspondente à institucionalidade, uma teoria da sociedade moderna, uma crítica das representações oriundas da participação imediata em práticas e instituições, e uma filosofia política como consolidação da vontade livre não apenas em instituições societárias, mas também estatais. $O$ resultado mais geral desse programa é a compatibilização, a interpenetração da segunda natureza forjada a partir daquelas representações com o rigor de uma teoria das instituições condizentes com a noção enfática de normatividade conceitual desenvolvida a partir da noção moderna de autodeterminação. "O sistema do direito é o reino da liberdade efetivada, o mundo do espírito produzido a partir do próprio espírito como uma segunda natureza" (HEGEL, 1970, 7, p. 45).

Parece-me que uma interpretação tal como esta que estou alinhavando pode ser respaldada no esclarecimento terminológico avançado por Hegel nos $\S \S 25$ e 26. Segundo a observação geral constante no $\S 26$, os componentes subjetivo e objetivo da vontade livre somente podem - e eis aí a marca inconfundível da estruturação dialética ${ }^{22}$ da liberdade concreta - ser compreendidos em sua relação recíproca. "Na vontade... que só pode ser sabida como o concreto, tais oposições, que devem ser abstratas e simultaneamente determinações desta vontade, conduzem por si mesmas a essa identidade das mesmas e à troca das suas significações" (HEGEL, 1970, 7, 76). A tese mais geral de Hegel parece ser a de que, para se compreender a vontade livre não se pode permanecer apenas na diferença estanque entre seus componentes, justamente porque eles somente são sabidos como o concreto, como "unidade de determinações diferentes" (Idem, 8, p. 176). Interessa-me aqui perseguir as decorrências desta ideia para as concepções mais enfáticas, mais legítimas (hochberechtigte) e, aparentemente, mais independentes de objetividade ${ }^{23}$ e subjetividade $^{24}$ : a

\footnotetext{
22 "Estas determinações lógicas de subjetividade e objetividade foram, aqui, especialmente arroladas, com a intenção de assinalar expressamente... que com elas ocorre o mesmo que com outras diferenças e determinações-da-reflexão contrapostas entre si, a saber, que elas, por causa da sua finitude e, portanto, da sua natureza dialética, passam ao seu oposto." (HEGEL, vol.7, p. 76)

23"a vontade objetiva, porém, enquanto desprovida da forma infinita da autoconsciência, é a vontade imersa no seu objeto ou no seu estado, como quer / que esteja constituída segundo o seu conteúdo" (HEGEL, op. cit., vol.7, p. 75/76). Neste sentido enfático, em cuja aparente e extrema independência a modernidade filosófica cai quase que "inconscientemente" (bewußtlos) (HEGEL, op. cit.., vol.7, p. 76) por força de sua própria dinâmica conceitual, ergue-se a pretensão de se falar numa pura institucionalidade,
} 
objetividade férrea do mundo institucional, do horizonte valorativo compartilhado, das orientações práticas seguidas de maneira imediata; por outro lado, a forma institucionalmente desconectada e pura da justificação de normas. Enfim, trata-se aqui daquilo que Hegel desenvolverá sob as noções de direito da subjetividade e direito da objetividade ${ }^{25}$. Com efeito, é a partir de redução proposital da envergadura da elucidação terminológica proposta por Hegel que eu gostaria de entender uma tese específica, bem como suas decorrências para a amplitude sui generis consitutiva do conceito hegeliano de direito.

Assim, a vontade, enquanto liberdade sendo interior a si, é a própria subjetividade; esta é, por isso, o conceito da vontade e, assim, a sua objetividade. Finitude, porém, é a sua subjetividade na oposição em face da objetividade; nessa oposição, precisamente, a vontade não está junto a si, ela está emaranhada com o objeto, e a sua finitude consiste, exatamente do mesmo modo, em não ser subjetiva etc. Qual a significação, portanto, que o subjetivo ou o objetivo da vontade devam ter, daqui para a frente, tem de ficar claro, cada vez,

numa substancialidade férrea e sobre a qual não se operou a autorreflexão. "Finalmente, pode-se, também, denominar de 'objetiva' a vontade que está inteiramente mergulhada no seu objeto, a vontade infantil, que, carecendo de liberdade subjetiva, repousa na confiança, e a vontade escrava, que não se sabe ainda como livre e é, por isso, uma vontade desprovida-de-vontade. 'Objetiva' nesse sentido é toda vontade que age dirigida por uma autoridade externa e que ainda não completou o retorno infinito (a)dentro de si." (Idem, vol.7, 77).

24 "a pura forma, a unidade absoluta da autoconsciência consigo mesma, unidade na qual a autoconsciência, enquanto eu $=\mathrm{eu}$, é absolutamente interior e [um] repousar abstrato sobre si - a pura certeza de si mesmo, diferente da verdade" (HEGEL, op. cit., vol.7, p. 75) Assim, sugere Hegel, apesar dos significados de "subjetividade" da vontade livre mais atrelados ao indivíduo particular, há que se reter sobretudo este como o mais legítimo, vinculado à dimensão efaticamente moderna da autodeterminação. 'Mas, então, pode ser igualmente chamado de 'subjetivo' aquele puro eu vazio, que só tem a si mesmo como ob-jeto e que possui a força de abstrair de todo conteúdo ulterior. A subjetividade tem, portanto, em parte, uma significação inteiramente particular, em parte, uma significação altamente legítima, já que tudo o que eu devo reconhecer, tem, também, a tarefa de tornarse algo meu e de obter validez em mim. Esta é a infinita cobiça da subjetividade, a de tudo reunir e consumir nesta fonte simples do puro eu" (HEGEL, op. cit., vol.7, p. 77).

25 "O direito de não reconhecer nada que eu não tenha discernido como racional é o direito supremo do sujeito, mas, pela sua determinação subjetiva, ao mesmo tempo, [um direito] formal, e contra ele permanece firmemente estabelecido o direito do racional enquanto [direito] do objetivo sobre o sujeito." (HEGEL, op. cit., vol.7, p. 244) Assim, para Hegel, o direito da objetividade significa a reivindicação feita pelo mundo institucional ou das práticas compartilhadas pelo reconhecimento prévio, por parte dos agentes, das regras pré-existentes e compartilhadas. $\mathrm{O}$ "direito da objetividade, correspondente à ação, assume a seguinte figura: visto que a ação é uma alteração que deve existir num mundo efetivo e quer, portanto, ser reconhecida neste, ela tem de ser em princípio conforme àquilo que tem validade nele. Quem quer agir nessa efetividade submeteu-se, precisamente por isso, a suas leis e reconheceu 0 direito da objetividade" (HEGEL, op. cit., vol.7, p. 245). 
a partir da conexão que contém a sua posição em relação à totalidade. (HEGEL, 1970, 7, p. 76).

A posição de Hegel neste trecho pode ser significativa, apesar (e talvez justamente por causa) do tom paradoxal que evoca a contradição da liberdade da vontade como arbítrio: a liberdade como interior, a própria subjetividade autodeterminante e autorreferente, embora devesse conter em si as condições de seu aporte objetivo e institucional (conceito de vontade), ao se retrair frente à objetividade, permanece na dimensão da finitude e, por isso mesmo, emaranhada (verwickelt) com o objeto, sem a força de completar "o retorno infinito (a)dentro de si” (HEGEL, 1970, 7, p. 77). Ora, justamente o esforço de pensar a necessária interpenetração entre o subjetivo e o objetivo, sem incorrer no abstracionismo institucional, mas sem perder a oportunidade de retornar (a)dentro de si a partir do envolvimento com formas limitadas e particulares de existência, eis aí, eu dizia, o elemento programático constitutivo do conceito hegeliano de direito.

Creio que os $\S \S 27$ e 28 desenvolvem este elemento programático na forma de uma discussão multifacetada sobre o estatuto normativo da filosofia do direito - em primeiro lugar com a ideia de que um tal estatuto normativo somente pode ser contemplado por uma teoria social normativa e, por conseguinte, por uma teoria normativa das instituições. "O impulso absoluto do espírito livre... [está] em que a sua liberdade seja ob-jeto para ele - que ela lhe seja objetiva tanto no sentido de ela ser o sistema racional do próprio espírito, quanto no sentido de que esse sistema seja efetividade imediata" (HEGEL, 1970, 7, p. 78). Nesse sentido, parece que Hegel pensa de uma dupla maneira esse movimento entre "conceito abstrato da ideia de vontade", "a vontade livre que quer a vontade livre", e a "objetividade": primeiro, o movimento pelo qual a liberdade se torna sistema racional e conceito desenvolvido, "vernünftiges System - entwickelter Begriff', configurando-se como efetividade imediata, isto é, como uma teoria normativa das instituições, o sistema de práticas comunitárias capazes de ser "produzidas" pelo próprio conceito, condizentes, portanto, com os critérios normativos decorrentes do próprio emblema moderno da autodeterminação, compatíveis com o que seria um processo de aferição de instituições e práticas orientado por essa normatividade que se recusa a permanecer puramente formal e subjetiva. Na verdade, Hegel pensa que este movimento nada mais é do que o que já está implícito no projeto moderno, depurado na noção de autodeterminação, a "atividade da vontade de suspender a contradição da subjetividade e da objetividade e de transpor os seus fins daquela determinação nesta, e, assim, ao mesmo tempo, permanecer na objetividade junto de si' (HEGEL, 1970, 7, p. 78). Mas, de acordo com Hegel, aquilo que propriamente faz com que o programa filosófico estabelecido em torno de sua 
noção de direito de fato ultrapasse "a modalidade apenas formal da consciência, na qual a objetividade existe somente como efetividade imediata" (Idem, 7, p. 78), é justamente o fato de que as exigências dessa postura meramente formal somente podem ser satisfeitas numa teoria normativa das instituições e, na medida em que com esta a efetividade deixa de ser puramente imediata - no sentido propositadamente indicado por Hegel de uma objetividade supostamente deprovida da forma infinita - numa postura que se confunde com a perspectiva de uma teoria normativa da sociedade moderna, isto é, uma teoria dos processos societários produzidos historicamente na modernidade, examinados em seu potencial para desenvolver práticas e instituições capazes de abrigar os modos específicos de justificação condizentes com a noção de liberdade como autodeterminação. Eis por que Hegel interpreta aquela atividade também como "desenvolvimento essencial do conteúdo substancial da idéia" (Idem, 7, p. 78). Essa substancialidade, uma totalidade de práticas e instituições historicamente produzidas e também perpasssada pela forma especificamente moderna de justificação, ultrapassa, em seu caráter bidirecional, a diferença, ainda marcante na filosofia política oci-dental, entre as dimensões subjetivas e objetivas da realização da liberdade. Essa tensão, essa bidirecionalidade, consitui a definição nominal, embora absolutamente sui generis, do direito à qual chega Hegel, "o fato de que um ser-aí em geral seja ser-aí da vontade livre" (HEGEL, 1970, 7, p. 79).

Entende-se melhor também porque Hegel percebe este ponto de chegada de sua introdução à Filosofia do Direito, ainda mais a tese de que sua concepção de direito é idêntica à "liberdade enquanto ideia" (Idem, 7, p. 79), como oferecendo a possibilidade para uma enfática marcação de posição em relação aos dois principais teóricos da liberdade enquanto autodeterminação, a saber: Rousseau e Kant. De acordo com Hegel, a definição puramente coercitiva e restritiva do direito, à qual chega Kant, embora muito mais conveniente e condizente com uma concepção negativa da liberdade - como talvez em Hobbes - está contido no programa geral desenvolvido por Rousseau de que "o que deve ser a base substancial e o primeiro não é a vontade enquanto sendo em si e para si, enquanto vontade racional, não é o espírito enquanto espírito verdadeiro, mas sim enquanto indivíduo particular/, enquanto vontade do singular em seu arbítrio próprio" (Idem, 7, p. 79-80) Hegel parece justamente acusar Rousseau - e, com ele, Kant - de haver concebido de maneira excessivamente subjetivizada o conceito de liberdade como autodeterminação. $\mathrm{O}$ que era para ser compreendido como investigação do enlace entre as dimensões subjetiva e objetiva da "liberdade enquanto ideia" (Idem, 7, p. 79), ou seja, a visualização das conexões entre os processos de justificação condizentes com a noção de autodeterminação e um quadro institucional 
apropriado, o qual não pode ser inteiramente separado daquela rede de práticas já produzidas pelos processos de modernização, torna-se, nas mãos de Rousseau - e, principalmente, nas de Kant - uma teoria focada na capacidade racional individual para a autodeterminação. Hegel retira então sua mordaz conclusão: se tudo que a liberdade como autodeterminação pode ser é uma faculdade individual, então, embora se possa esperar que instituições se compatibilizem fortuitamente com dimensão subjetiva da liberdade, em geral a racionalidade das instituições e práticas teria de ser pensada como extrínseca, exterior, coercitiva, estranhada e, com isso, opressiva. $\mathrm{O}$ "racional só pode vir à luz enquanto restringindo essa liberdade, assim como, também, não enquanto algo imanentemente racional, mas sim, enquanto um universal externo, formal" (Idem, 7, p. 80). Mais claro ainda fica o fato de que Hegel possa assim ver, na subjetivização da autodeterminação, não somente uma perspectiva filosoficamente insuficiente, mas sobretudo uma perspectiva que, por ser proveniente do mesmo processo pelo qual a modernidade sucumbe a um sistema insuficiente de racionalidade ${ }^{26}$, se desenvolve em paralelo com descaminhos e insuficiências não simplesmente filosóficas, mas concretizadas em práticas, instituições, no mundo da vida. "Esse ponto de vista está desprovido de todo pensamento especulativo e é rejeitado pelo conceito filosófico, porquanto ele produziu, nas cabeças e na efetividade, fenômenos, cujo horror só tem paralelo na trivialidade dos pensamentos nos quais se fundavam” (HEGEL, 1970, 7, p. 80) Assim, para Hegel, a subjetivização kantiana da autodeterminação nada mais é do que a expressão, na filosofia prática moderna, do formalismo, o qual, de resto, é não somente a marca inconfundível da insuficiência do paradigma moderno de racionalidade, como ainda se conecta de múltiplas formas com os fenômenos da "positividade" (Idem, 1, p. 321-322), da cisão (Idem, 2, p. 20) e da ruptura na eticidade moderna (Idem, 7, p. 339). Eis por que, embora a modernidade tenha inventado o conceito de liberdade como autodeterminação, a maneira formal e

\footnotetext{
26 Tomo esta noção de "sistema insuficiente de racionalidade" da percepção proposta por Honneth acerca da inspiração de Hegel nas diretrizes teóricas assumidas pela teoria crítica (HONNETH, A. "Uma Patologia Social da Razão: sobre o legado intelectual da Teoria Crítica". In: RUSH, F. Teoria Crítica. Aparecida (SP): Editora Ideias e Letras, 2008. p. 393), e de sua leitura da Filosofia do Direito. Honneth interpreta a tese de que a eticidade constitui o fundamento e a efetivação dos padrões de racionalidade típicos do direito privado e da moral da autonomia (\$§141, p. 261) no sentido de um vínculo interno entre teoria da justiça e diagnóstico de época, entre a teoria da eticidade como teoria normativa da modernidade, e a percepção dos limites e riscos de uma absolutização das estruturas racionais que constituem a pessoa de direito e o sujeito moral (HONNETH, A. Sofrimento de Indeterminação. São Paulo: Editora Singular/Esfera Pública, 2007. p. 80 e seg). As instituições e práticas da eticidade colaboram na formação das capacidades subjetivas associadas especificamente ao ser-pessoa e ao sersujeito (HONNETH, op. cit., p. 138). Ver também: NEUHOUSER, 2000. cap. IV e V.
} 
subjetivizada como a concebe faz com que a filosofia prática, resumida por Hegel no seu conceito de direito como conexão entre justificação e institucionalidade, perca seu aguilhão e sua envergadura, sua sacralidade, a conexão indissociável entre subjetividade e objetividade, entre justificação e institucionalidade, conexão que compõe a verdadeira infinitude da liberdade"O direito é em princípio algo de sagrado, unicamente porque ele é o ser-aí do conceito absoluto, da liberdade autoconsciente. - Mas o formalismo do direito (e, mais adiante, o do dever) surge da diferença [resultante] do desenvolvimento do conceito de liberdade" (Idem, 7, p. 82).

\section{0 Sentido Geral do Programa Filosófico Contido na Filosofia do Direito de Hegel: a envergadura de uma filosofia prática normativa}

Talvez a maneira mais interessante de perceber o impacto da noção hegeliana de direito sobre toda aquela dimensão pensada tradicionalmente sob o título de "filosofia prática" seja vincular tal noção ao projeto de "doutrina imanente dos deveres", bem como a relação desta com os impulsos. Mostrei acima como Hegel pretende que seu esforço na Filosofia do Direito tenha um traço em comum com a exigência, de resto indeterminada, de "purificação dos impulsos" (HEGEL, 1970, 7, p. 69), a saber: que também nesse tópico clássico se tenda a pensar a organização sistemática racional dos impulsos como determinações da vontade. Em linhas gerais, como vimos, o esforço da Filosofia do Direito consiste, em última instância, em apreender o conteúdo volitivo e pulsional na forma de uma sistematização racional enquanto "deveres" (Idem), ou seja, enquanto um tecido de práticas compartilhadas condizentes com o emblema moderno da justificação moral. Embora eu não possa, na presente ocasião, desenvolver meu argumento no sentido de uma apreciação da crítica de Hegel a Kant, explicitada por exemplo nos $\S \S 129-157$, tarefa que inspirará certamente uma nova incursão pelo texto de Hegel, julgo apropriado lembrar que Hegel, a despeito de tudo o que comporta tão célebre passagem, atribui à perspectiva kantiana não propriamente um caráter absolutamente equívocado, mas uma insensibilidade, um impedimento, uma incapacidade. Com a crítica à moralidade kantiana pela sua renitente abstração do contexto, quando, mesmo sendo autodeterminação ou "pensamento da autonomia infinita da vontade" (HEGEL, 1970, 7, p. 251), se comporta como "identidade sem conteúdo ou o positivo abstrato" (Idem), Hegel pretende sustentar que se estabeleceria assim um obstáculo intransponível à passagem para o ponto de vista da eticidade, o que, segundo ele, tem por decorrência a impossibilidade para uma doutrina 
imanente dos deveres: "apegar-se ao mero ponto de vista moral, que não faz a passagem ao conceito de eticidade, rebaixa igualmente esse ganho a um formalismo vazio e a ciência moral a uma falação sobre o dever em vista do dever... não se pode passar à determinação de deveres particulares" (Idem). Com certa liberdade interpretativa, poderíamos ver nesse encaminhamento geral o projeto de transformar a dimensão categórica da justificação em termos de autodeterminação, desenvolvida sobretudo por Rousseau e Kant, numa fiosofia prática de alcance mais aristotélico, isto é, comprometida com a sensibilidade para práticas e instituições. Ora, para dizer a verdade, num tal projeto nem Kant nem Aristóteles subsistem incólumes ${ }^{27}$, pois se trata ainda de uma filosofia prática normativa, capaz de se desdobrar numa teoria normativa das práticas e instituições, bem como numa filosofia social de matriz crítica e, portanto, enfaticamente normativa.

\section{Referências}

ADORNO, T. e HORKHEIMER, M. Dialética do Esclarecimento: Fragmentos Filosóficos. Jorge Zahar Editora: Rio de Janeiro, 1985.

ADORNO, T. Dialética Negativa. Jorge Zahar Editora: Rio de janeiro, 2009. BERNSTEIN, J. Recovering Ethical Life: Jürgen Habermas and Future of Critical Theory. Routledge: New York, 1995, p. 19-50.

BERSTEIN, R. The Pragmatic Turn. Polity Press: Cambridge, 2010.

BRANDOM, R. Tales of the Mighty Dead: Historical Essays in the Metaphysics of Intentionality. Cambridge: Harvard University Press, 2002.

FISCHBACH, F. Fichte et Hegel: la reconnaissance. Paris: Presses Universitaires de France, 1999.

FORST, R. "Kommunitarismus und Liberalismus: Stationen einer Debatte". In: HONNETH, A. Kommunitarismus und Liberalismus: eine Debatte über die moralischen Grundlagen moderner Gesellschaften. Frankfurt am Main: Campus, 1995.

HABERMAS, J. "Arbeit und Interaktion. Bemerkungen zu Hegels Jenenser 'Philosophie des Geites". In: GÖHLER, G. Frühe politische Systeme. Frankfurt am Main: Ullstein, 1974.

. Consciência Moral e Agir Comunicativo. Rio de Janeiro: Tempo Brasileiro, 1989.

27 Honneth insiste em que sua reformulação do paradigma hegeliano de intersubjetividade e reconhecimento prenuncia uma ultrapassagem da dicotomia entre a ética aristotélica e a moral kantiana da autonomia (HONNETH, 2000) e poderia conduzir à "descoberta de uma alternativa na qual ambos os pontos de vista são de tal forma integrados que com isso nós podemos viver uma vida menos cindida", um programa no qual Honneth vê "a tarefa central de uma teoria moral hoje." (Idem, p. 172) 
. Escritos sobre moralidad y eticidad. Barcelona: Padiós, I.C.E-U.A.B, 1991. Paulo, 2001.

A Constelação Pós-nacional: Ensaios Políticos. Littera Mundi: São

. Racionalidade e Comunicação. Lisboa: Edições 70, 2002a.

"Werte und Normen. Ein Kommentar zu Hilary Putnams Kantischen Pragmatismus". In: RATERS M.-L. \& WILLASCHEK, M. Hilary Putnam und die Tradition des Pragmatismus. Frankfurt am Main: Suhrkamp, 2002b, p. 280305 .

. Discurso filosófico da modernidade. São Paulo: Martins Fontes, 2002c.

. Verdade e Justificação: ensaios filosóficos. São Paulo: Loyola, 2004.

Teoria do Agir Comunicativo. Volume 1 (Racionalidade da Ação e Racionalização Social). São Paulo: WMF-Martins Fontes, 2012.

HEGEL, G. W. F. Werke in 20 Bände. Frankfurt am Main: Suhrkamp, 1970.

HONNETH, A. Kampf um Anerkennung. Zur moralischen Grammatik sozialer Konflikte. Frankfurt am Main: Suhrkamp, 1992.

. Kommunitarismus: eine Debatte über die moralischen Grundlagen moderner Gesellschaften. Frankfurt am Main: Suhrkamp, 1995.

. "Zwischen Aristoteles und Kant: Skizze einer Moral der Anerkennung". In: HONNETH, A. Das Andere der Gerechtigkeit: Aufsätze zur praktischen Philosophie. Frankfurt am Main: Suhrkamp, 2000.

- "Gerechtigkeit und Kommunikative Freiheit: Überlegungen im Anschluss an Hegel”. In: Merker, B. - Subjektivität und Anerkennung. Frankfurt am Main: Mentis, 2004.

. Sofrimento de Indeterminação. São Paulo: Editora Singular/Esfera Pública, 2007.

Mead, G. H. Geist, Identität und Gesellschaft. Frankfurt am Main: Suhrkamp, 2005.

KANT, I. Kants Werke - Akademie Textausgabe. Berlin: Walter de Gruyter, 1968.

NEUHOUSER, F. Foundations of Hegel's Social Theory: actualizing freedom. Cambridge: Cambridge Univ. Press, 2000.

O'CONNOR, B. Adorno's Negative Dialectic: Philosophy and Possibility of Critical Rationality. London: The MIT Press, 2004.

PATTEN, A. Hegel's Idea of Freedom. Oxford: Oxford Univ. Press, 1999.

PINKARD, T. Hegel's Phnomenology. The Sociality of Reason. Cambridge: Cambridge University Press, 1996.

PIPPIN, R. Hegel's Practical Philosophy: Rational Agency as Ethical Life. Cambridge: Cambridge University Press, 1989. 
PUTNAM, H. “Werte und Normen”. In: WINGERT, L. \& GÜNTHER, K. Die Öffentlichkeit der Vernunft und die Vernunft der Öffentlichkeit. Festschrift für Jürgen Habermas. Frankfurt am Main: Suhrkamp, 2001, p. 280-313.

“Antwort auf Jürgen Habermas”. In: RATERS M.-L. \& WILLASCHEK, M. Hilary Putnam und die Tradition des Pragmatismus. Frankfurt am Main: Suhrkamp, 2002a., p.306-321.

Letras, 2002b.

. Colapso da Verdade e outros Ensaios. Aparecida/SP: Editora Idéias e

QUANTE, M. Hegels Erbe. Frankfurt am Main: Suhrkamp, 2004.

. Die Wirklichkeit des Geistes: Studien zu Hegel. Frankfurt am Main:

Suhrkamp, 2011.

REDDING, P. Analytic Philosophy and the Return of Hegelian Thought. New York: Cambridge University Press, 2007.

ROCKMORE, T. Hegel, Idealism, and Analytic Philosophy. New York: Yale University Press, 2005.

SCHNÄDELBACH, H. Hegels praktische Philosophie: Ein Kommentar der Texte in der Reihenfolge ihrer Entstehung. Frankfurt am Main: Suhrkamp, 2000.

SIEP, L. Anerkennung als Prinzip der praktischen Philosophie. Freiburg/München: Alber, 1979.

. "Was heißt: 'Aufhebung der Moralität in der Sittlichkeit' in Hegels Rechtsphilosophie". In: Praktische Philosophie im deutschen Idealismus. Frankfurt am Main: Suhrkamp, 1992, p. 217-39.

. Der Weg der Phänomenologie des Geistes. Ein einführender Kommentar zu Hegels "Differenzschrift" und "Phänomenologie des Geistes". Frankfurt am Main: Suhrkamp, 2000.

THEUNISSEN, M. "Die verdrängte Intersubjektivität in Hegels Philosophie des Rechts". In: HENRICH, D.; HORSTMANN, R. Hegels Philosophie des Rechts. Die Theorie der Rechtsformen und ihre Logik. Stuttgart: Reclam, 1982, p. 317-81. WITTGENSTEIN, L. Werkausgabe in 8 Bänden. Frankfurt: Suhrkamp, 1984. 